\title{
PROBLEMATIKA PENYIDIK KEJAKSAAN NEGERI BANGKINANG DALAM MENANGANI TINDAK PIDANA KORUPSI DANA DESA
}

\author{
Tri Novita Sari Manihuruk ${ }^{1}$, Riantika Pratiwi² \\ Dosen Fakultas Hukum Universitas Lancang Kuning
}

\begin{abstract}
Village funds in Riau Province are often targeted for corruption. The large amount of misappropriation of village funds has caused losses to State finances and has caused unrest in every community. Facts in the field show the high number of corruption cases of village funds in Riau Province, one of which is in Kampar Regency. This study aims to manage the crime problem and the efforts of the Bangkinang District Attorney's Office in the criminal act of village fund corruption. This research uses empirical legal research, namely research that provides legal authority in society. Technique of data by means of observation, interviews, and literature review. The results of the study concluded that the problems of the state prosecutor's office in the corruption crime of village funds include; First, there are different perceptions of law enforcers in calculating state financial losses. Second, the difficulty of presenting documents. Third, the convict does not have the property to pay money for state financial losses. As for the efforts; First, law enforcers will conduct case titles involving the Riau Police, the Kampar Police, the National Police Headquarters, the Riau Provincial BPKP, the Attorney General's Office, the Riau High Prosecutor's Office and the Bangkinang Attorney General's Office. The order of the case titles agreed that the auditors used were auditors from the Inspectorate of Kampar Regency. Second, the Bangkinang District Prosecutor's Office conducts an asset search of the convict's assets, in order to pay money for state financial losses. However, in fact, an asset investigation was carried out which turned out that the convicted corruption convict did not pay money, so he preferred a subsidiary
\end{abstract}

Keywords:

Corruption, Village funds, Prosecutor

\begin{abstract}
Abstrak
Dana desa di Provinsi Riau kerap kali dijadikan sebagai sasaran korupsi. Banyaknya penyelewengan dana desa tersebut menimbulkan kerugian keuangan Negara serta menimbulkan keresahan di setiap masyarakat. Fakta dilapangan menunjukkan tingginya kasus korupsi dana desa di Provinsi Riau, salah satunya di Kabupaten Kampar. Penelitian ini bertujuan menganalisis
\end{abstract}


problematika dan upaya Kejaksaan Negeri Bangkinang dalam menangani tindak pidana korupsi dana desa. Penelitian ini menggunakan jenis penelitian hukum empiris, yaitu penelitian yang mencermati efektivitas hukum di dalam masyarakat. Teknik pengumpulan data dengan cara observasi, wawancara, dan kajian pustaka. Hasil penelitian menyimpulkan bahwa Problematika penyidik kejaksaan negeri bangkinang dalam menangani tindak pidana korupsi dana desa diantaranya; Pertama, Adanya Perbedaan Persepsi penegak hukum dalam menghitung kerugian keuangan Negara, Kedua, Sulitnya menghadirkan saksi, Ketiga, Terpidana tidak memiliki harta untuk membayar uang pengganti atas kerugian keuangan Negara. Adapun Upayanya; Pertama, Penegak hukum melakukan gelar perkara dengan melibatkan Polda Riau, Polres Kampar, Mabes Polri, BPKP Provinsi Riau, Kejaksaan Agung, Kejaksaan Tinggi Riau dan Kejaksaan Bangkinang. Sehinga dari gelar perkara tersebut disepakati bahwa Auditor yang digunakan adalah auditor dari Inspektorat Kabupaten Kampar. Kedua, Kejaksaann Negeri Bangkinang melakukan Penelurusan asset terhadap harta kekayaan terpidana, guna untuk membayar uang pengganti atas kerugian keuangan Negara. Namun faktanya, setelah dilakukan penelusuran asset ternyata terpidana korupsi tidak membayar uang pengganti, sehingga lebih memilih subsider.

Kata Kunci:

Korupsi, Dana Desa, Kejaksaan

\section{A. PENDAHULUAN}

$\Gamma$ Tata kelola dana desa belum sepenuhnya bebas dari korupsi. Dana desa dijadikan sebagai sasaran korupsi bagi Tersangka. Sejak diundangkannya _ Undang-Undang Desa Nomor 6 Tahun 2014, undang-undang ini memberikan kewenangan secara otonom kepada pemerintah desa dalam mengelola dan mengembangkan desanya. Masyarakat desa lebih sejahtera dengan berbagai program pemberdayaan dan pengelolaan sumber daya desa. Pemerintah desa dapat melakukan pola peningkatan ekonomi desa melalui Badan Usaha Milik Desa (BUMDes), mengatur Anggaran Pendapatan dan Belanja Desa (APBDes) serta melakukan berbagai pembangunan infrastruktur yang dapat menunjang peningkatan ekonomi desa. Dari desa membangun negeri menjadi terwujud. ${ }^{1}$

Sejak bergulir tahun 2015 hingga saat ini, dana desa yang sudah digelontorkan pemerintah berjumlah Rp 186 triliun. Dana ini sudah disalurkan ke 74.954 desa di seluruh wilayah Indonesia. Dalam perkembangannya, dana desa yang berlimpah tersebut rawan praktik korupsi. Berdasarkan hasil pemantauan Indonesia Corruption Watch ( ICW) sejak tahun 2015 hingga Semester I 2018, kasus korupsi dana desa mengalami peningkatan dari tahun ke tahun. Tercatat sedikitnya sudah ada 181 kasus korupsi dana desa dengan 184 tersangka korupsi dan nilai kerugian sebesar Rp

${ }^{1}$ Marten Bunga, Aan aswari, Konsepsi Penyelamatan Dana Desa dari Perbuatan Korupsi, Jurnal Horlev, Vol 2, No. 2, 2018, hlm. 452.

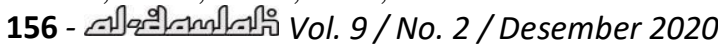


40,6 miliar. ${ }^{2}$ Tercatat, ada 17 kasus pada tahun 2015. Pada tahun kedua, jumlahnya meningkat menjadi 41 kasus. Sementara, pada 2017, korupsi dana desa melonjak lebih dari dua kali lipat menjadi 96 kasus. Sementara pada semester I tahun 2018, terdapat 27 kasus di desa yang semuanya menjadikan anggaran desa sebagai objek korupsi. Dari segi pelaku, kepala desa menjadi aktor terbanyak untuk kasus korupsi dana desa. Pada 2015, 15 kepala desa menjadi tersangka; 2016 jumlahnya meningkat menjadi 32 kepala desa, dan jumlahnya meningkat lebih dari dua kali lipat menjadi 65 orang pada $2017 .^{3}$

Dana desa di Riau kerap kali dijadikan sebagai sasaran korupsi. Banyaknya penyelewengan dana desa tersebut menimbulkan kerugian keuangan Negara serta menimbulkan keresahan di setiap masyarakat. Fakta dilapangan menunjukkan tingginya kasus korupsi dana desa di Provinsi Riau. Bahwa berdasarakan wawancara Penulis dengan Bapak Pangucap Priyo, SIK selaku Kasubdit Direktorat Reserse Kriminal Khusus pada Kepolisian Negara Republik Indonesia Daerah Riau (POLDA RIAU) mengatakan bahwa ada beberapa kasus korupsi dana desa yang terjadi di Provinsi Riau diantaranya Kabupaten Kampar, Rokan Hilir, Bengkalis dan Kabupaten Kepulauan Meranti. Sementara korupsi dana desa di Kabupaten Kampar yang ditangani oleh Kejaksaan Negeri Bangkinang tercatat sedikitnya ada 2 kasus korupsi dana desa dengan 2 Tersangka. Berikut dapat dilihat pada tabel berikut:

Tabel 1.1

Jumlah Kasus Korupsi Dana Desa di Kejaksaan Negeri Bangkinang

\begin{tabular}{|c|l|c|c|c|}
\hline No & \multicolumn{1}{|c|}{ Kasus } & Tahun & Pelaku & \multicolumn{1}{c|}{$\begin{array}{c}\text { Kerugian } \\
\text { Keuangan Negara }\end{array}$} \\
\hline 1 & $\begin{array}{l}\text { Desa Kampung } \\
\text { Panjang, Desa Sungai } \\
\text { Jalau, Desa Muara Jalai } \\
\text { dan Desa Sungai } \\
\text { Tonang Kecamatan } \\
\text { Kampar }\end{array}$ & 2016 & $\begin{array}{c}\text { Kepala } \\
\text { Desa }\end{array}$ & 274.959 .700 \\
\hline 2 & $\begin{array}{l}\text { Desa Gunung Malelo, } \\
\text { Kecamatan Koto } \\
\text { Kampar Hulu) }\end{array}$ & 2016 & $\begin{array}{l}\text { Kepala } \\
\text { Desa }\end{array}$ & 335.963 .575 .70 \\
\hline
\end{tabular}

Sumber: Data Olahan dari Polda Riau, Kejaksaan Negeri Bangkinang

Bahwa berdasarkan tabel tersebut, terlihat jumlah korupsi dana desa yang ditangani oleh Kejaksaan Negeri Bangkinang tercatat sedikitnya ada 2 kasus dengan 2 Tersangka yaitu Kepala Desa. Dengan nilai kerugian keuangan Negara yang berbeda-beda. Dimana pada daerah tersebut memang benar ditemukan adanya

${ }^{2}$ ICW Ada 181 Kasus Korupsi Dana Desa, Rugikan Negara Rp 40,6 Miliar $\leq$ https://nasional.kompas.com/read/2018/11/21/19000481/icw-ada-181-kasus-korupsi-dana-desa-rugikan-negararp-406-miliar?page $=$ all $\geq$ diakses tanggal 21 Juni 2019

${ }^{3}$ Ibid 
kasus korupsi dana desa. Terjadinya praktik korupsi dana desa di Kabupaten Kampar tentu tidak bisa diabaikan begitu saja. Tentunya penegakan hukum pidana sebagai ultimum remedium dalam menyelesaikan masalah ini diharapkan mampu mengembalikan kerugian keuangan Negara.

Dalam hal penegakan tindak pidana korupsi di daerah ada dua penegak hukum yang lebih dominan dalam pelaksanaan penyidikan tindak pidana korupsi yaitu kepolisian dan kejaksaan walaupun komando penegakan hukum terhadap tindak pidana korupsi tetap ada di Komisi Pemberantasan Korupsi setelah lahirnya Undang-Undang Nomor 30 Tahun 2002 Komisi Pemberantasan Korupsi. ${ }^{4}$

Kewenangan kepolisian dan jaksa sebagai penyidik tindak pidana korupsi diatur secara tegas dalam Pasal 50 Undang-Undang Nomor 30 Tahun 2002 tentang Komisi Pemberantasan Korupsi, yang menyebutkan:

1) Dalam hal suatu tindak pidana korupsi terjadi dan Komisi Pemberantasan Korupsi belum melakukan penyidikan, sedangkan perkara tersebut telah dilakukan penyidikan oleh kepolisian atau kejaksaan, instansi tersebut wajib memberitahu kepada komisi pemberantasan korupsi paling lambat 14 hari kerja terhitung sejak tanggal dimulainya penyidikan.

2) Penyidikan yang dilakukan oleh kepolisian atau kejaksaan sebagaimana dimaksud pada ayat (1) wajib dilakukan koordinasi secara terus menerus dangan Komisi Pemberantasan Korupsi.

3) Dalam hal Komisi Pemberantasan Korupsi sudah mulai melakukan penyidikan sebagaimana dimaksud pada ayat (1) kepolisian atau kejaksaan tidak berwenang lagi melakukan penyididkan.

4) Dalam hal penyidikan dilakukan secara bersama oleh kepolisian dan/atau kejaksaan dan Komisi Pemberantasan Korupsi yang dilakukan oleh kepolisian atau kejaksaan tersebut segera dihentikan.

Dari uraian tersebut, terlihat bahwa Lembaga yang berwenang melakukan Penyidikan tindak pidana korupsi ada tiga yaitu Kepolisian, Kejaksaan dan KPK. Dalam hal Penyidikan dilakukan oleh Penyidik Kepolisian, maka prosedur penanganan perkaranya sama dengan prosedur penanganan tindak pidana pada umumnya, yaitu berkas hasil penyidikan diserahkan kepada Jaksa Penuntut Umum di Kejaksaan sesuai dengan daerah hukumnya. Apabila Jaksa Penuntut Umum berpendapat bahwa berkas perkara telah memenuhi syarat formil dan material, maka berkas perkara akan dilimpahkan ke pengadilan tindak pidana korupsi. Dalam hal penyidikan tindak pidana korupsi dilakukan oleh Penyidik KPK, maka penyidik KPK akan menyerahkan berkas hasil penyidikan kepada Jaksa Penuntut Umum di Kejaksaan untuk selanjutnya dilimpahkan ke Pengadilan Tindak Pidana Korupsi. Dalam hal penyidikan perkara tindak pidana korupsi dilakukan oleh Penyidik Kejaksaan, maka berkas perkara hasil penyidikan akan diteruskan ke Jaksa Penuntut Umum di Kejaksaan untuk selanjutnya dilimpahkan ke Pengadilan Tindak Pidana

\footnotetext{
${ }^{4}$ Achmad Surya, Problematika Penyidik dalam Penetapan Tersangka Tindak Pidana Korupsi Dana Desa di Kabupaten Aceh Tengah, Resam Jurnal Hukum Sekolah Tinggi Ilmu Hukum Muhammadiyah Aceh tengah, Vol. 4, No. 1, 2018, hlm. 31-44 158 -
} 
Korupsi. ${ }^{5}$

Kasus Korupsi Dana Desa yang ditangani oleh Kejaksaan Negeri Bangkinang tidak serta merta berjalan dengan lancar, terdapat beberapa problematika dalam penegakan hukumnya. Sehingga perlu dilakukan kajian tentang masalah ini.

\section{B. METODE PENELITIAN}

Penelitian ini menggunakan jenis penelitian hukum empiris. Jenis penelitian hukum empiris bertujuan untuk mencermati efektivitas hukum didalam masyarakat. Penelitian hukum empiris merupakan kajian yang mengungkapkan apa adanya fakta. Penelitian ini akan mengidentifikasi berbagai problematika penyidik kejaksaan Negeri Bangkinang dalam menangani tindak pidana korupsi dana desa.

Teknik pengumpulan data dalam penelitian ini berdasarkan observasi, wawancara, dan kajian pustaka. Perbedaan teknik pengumpulan data ini disebabkan perbedaan responden dalam penelitian ini. Penelitian ini menggunakan metode analisa data kualitatif, yaitu suatu cara analisis yang menghasilkan data deskriptif analitis, yaitu apa yang dipaparkan oleh responden secara lisan atau tulisan, perilaku obyek yang diteliti, dan dipelajari secara utuh. ${ }^{6}$

Untuk memperoleh data dalam penelitian ini, maka para responden dalam penelitian ini sebagai berikut : Penyidik Kejaksaan Negeri Bangkinang, Polres Kampar, Hakim Pengadilan Tipikor Pekanbaru.

\section{HASIL DAN PEMBAHASAN}

\section{Problematikan Penyidik Kejaksaan Negeri Bangkinang dalam Menangani Tindak Pidana Korupsi Dana Desa}

Kasus Korupsi Dana Desa yang ditangani oleh Kejaksaan Negeri Bangkinang tidak serta merta berjalan dengan lancar, terdapat beberapa problematika dalam penegakan hukumnya. Sesuai dengan teori penegakan hukum, sebagaimana yang dikemukakan oleh Soerjono Soekanto bahwa masalah pokok penegakan hukum sebenarnya terletak pada faktor-faktor yang mempengaruhinya, yang mengakibatkan penegakan hukum tersebut tidak bisa berjalan maksimal. Faktorfaktor tersebut terdiri dari faktor hukumnya sendiri, faktor penegak hukum, faktor sarana atau fasilitas, aktor masyarakat dan faktor kebudayaan. Berdasarkan wawancara penulis dengan Bapak Pujo, SH dan Bapak Amri Rahmanto, SH, Adapun problematika Penyidik Kejaksaan Negeri Bangkinang dalam menangani tindak pidana korupsi dana desa di kabupaten Kampar ini yaitu: ${ }^{7}$

a. Perbedaan Persepsi penegak hukum dalam menghitung kerugian keuangan

\footnotetext{
${ }^{5}$ Yudi Kristiana, Teknik Penyidikan dan Pemberkasan Tindak Pidana Korupsi, Thafamedia, Yogyakarta 2018. Hlm 16

${ }^{6}$ Soerjono Soekanto, Pengantar Penelitian Hukum, (Jakarta:UI Press, 2008), hlm. 154.

${ }^{7}$ Wawancara dengan Bapak Pujo, SH dan Bapak Amri Rahmanto, SH Kepala Dinas selaku Penyidik Kejaksaan Bnagkinang, tanggal 17 Juni 2019, pukul 11.00 WIB, di Kantor Kejaksaan Negeri Bangkinang
} 


\section{Negara}

Berdasarkan wawancara penulis dengan Bapak Pujo, SH dan Bapak Amri Rahmanto, SH ada dua kasus korupsi dana desa yang pernah ditangani. Yaitu kasus iskandar (lanjutan dari polres Kampar), dan kasus Suhailis Chan (berdasarkan temuan Intelijen kejaksaan Kampar). Dimana motiv kedua kasus tersebut berbeda. Untuk kasus Iskandar, korupsi tersebut terjadi pada tahun 2015. Ketika itu Pelaku selaku Camat Kampar Utara juga menjadi Pejabat Sementara (Pjs) empat kepala desa (kades) yakni, Kampung Panjang, Sungai Jalau, Muara Jalai dan Sei Tonang. Dana yang bersumber dari APBN 2015 untuk empat desa diantaranya diselewengkan. Saat pencairan dana, sebagian dana desa disimpan oleh Iskandar. Selanjutnya dana tersebut dimasukkan ke dalam rekening pribadinya. Pencairan dana tersebut untuk kegiatan pembangunan fisik berupa semenisasi jalan dan pembuatan irigasi desa. Namun pengerjaanya tidak melalui mekanisme yang benar. Atas perbuatan Iskandar tersebut ditemukan kerugian Negara sebesar Rp. 274.959.700

Kasus Suhailis Chan, mantan Pejabat Kades Malelo, Kabupaten Kampar melakukan penyelewengan dana desa. Diketahui bahwa tidak hanya dana desa saja, tetapi sumber keuangan Dana Desa secara komprehensif. Diantaranya dana PAD (Pendapatan Asli Desa), Dana Desa, Alokasi Dana Desa (ADD), dan Bagi Hasil, Atas perbuatan Suhailis chan tersebut ditemukan kerugian Negara sebesar Rp. 335.963.575.70.

Salah satu unsur yang mendasar dalam tindak pidana korupsi adalah adanya kerugian keuangan negara. ${ }^{8}$ UU Tipikor yang saat ini berlaku tidak mendefinisikan serta mengatur secara tegas dan pasti mengenai apa yang dimaksud dengan kerugian negara. Definisi kerugian negara diatur dalam peraturan yang lain seperti UU Pembendaharaan Negara dan UU BPK. Undang-

Undang Nomor 1 Tahun 2004 tentang Perbendaharaan Negara, Pasal 1 ayat 22 menjelaskan "Kerugian negara/ daerah adalah kekurangan uang, surat berharga, dan barang, yang nyata dan pasti jumlahnya sebagai akibat perbuatan melawan hukum baik sengaja maupun lalai." Berdasarkan pengertian di atas, dapat dikemukakan unsur-unsur dari kerugian negara yaitu: 1) Kerugian negara merupakan berkurangnya keuangan negara berupa uang berharga, barang milik negara dari jumlahnya dan/ atau nilai yang seharusnya; 2) Kekurangan dalam keuangan negara tersebut harus nyata dan pasti jumlahnya atau dengan perkataan lain kerugian tersebut benar-benar telah terjadi dengan jumlah kerugian yang secara pasti dapat ditentukan besarnya, dengan demikian kerugian negara tersebut hanya merupakan indikasi atau berupa potensi terjadinya kerugian; 3) Kerugian tersebut akibat perbuatan melawan hukum, baik sengaja maupun lalai, unsur melawan hukum harus dapat dibuktikan secara cermat dan tepat. Berdasarkan ketentuan Pasal 1 ayat 22 Undang-Undang Nomor 1 Tahun 2004 sebagaimana di kemukakan di atas, dapat dilihat bahwa konsep yang dianut adalah konsep kerugian negara dalam arti delik materiil. 
Suatu perbuatan dapat dikatakan merugikan keuangan negara dengan syarat harus adanya kerugian negara yang benar-benar nyata. Hal ini berbeda dengan Pasal 2 ayat (1) UU Tipikor yang menjelaskan bahwa kerugian negara dalam konsep delik formil dikatakan dapat merugikan keuangan negara atau perekonomian negara. Pasal 1 angka 15 Undang-Undang Nomor 15 Tahun 2006 tentang Badan Pemeriksa Keuangan,menjelaskan kerugian negara/ daerah adalah kekurangan uang, suratberharga, dan barang, yang nyata dan pasti jumlahnya, sebagai akibat perbuatanmelawan hukum baik sengaja maupun lalai. Selain menurut UU BPK, BPKP menilaibahwa dalam kerugian keuangan/ kekayaan negara, suatu kerugian negara tidak hanyayang bersifat riil, tetapi juga yang bersifatpotensial yaitu yang belum terjadi seperti adanya pendapatan negara yang akan diterima. ${ }^{9}$

Undang-Undang Tipikor khususnya Pasal 2 dan Pasal 3 tidak menyebutkan secara eksplisit mengenai siapa instansi atau pihak mana yang berwenang dalam menentukan perhitungan kerugian Negara. Di dalam praktik, institusi yang seringkali dilibatkan oleh penegak hukum dalam menghitung kerugian Negara adalah Badan Pemeriksa Keuangan (BPK) dan Badan Pengawasan Keuangan dan Pembangunan (BPKP). ${ }^{10}$ Diluar kedua institusi tersebut misalkan penghitungan kerugian Negara juga dapat dilakukan oleh akuntan public. Bahkan dalam beberapa perkara Pihak Kejaksaan dan Pengadilan pernah melakukan sendiri penghitungan kerugian keuangan Negara. Selain BPK, Badan Pengawasan Keuangan dan Pembangunan (BPKP) juga berwenang untuk menetapkan mengenai adanya kerugian Negara. Ini terkait dengan fungsi BPKP yaitu melaksanakan pengawasan terhadap keuangan dan pembangunan. Kewenangan Badan ini dituangkan dalam Surat Keputusan Presiden Nomor 31 Tahun 1983 yang menyatakan BPKP memiliki kewenangan menghitung kerugian Negara.

Bahwa berdasarkan wawancara dengan Bapak Muhammad Zikri, Selaku Penyidik di Kepolisian Kampar, ada perbedaan persepsi antara kepolisian dengan kejaksaan bangkinang dalam menentukan kerugian keuangan Negara. Oleh kepolisian menggunakan auditor dari Inspektorat Kabupaten Kampar, sedangkan oleh Kejaksaan bangkinang menggunakan auditor dari BPKP Provinsi Riau. Sehingga hal ini menyebabkan terkendalanya penegakan hukum itu sendiri.

\section{b. Sulitnya Menghadirkan Saksi}

Bahwa penegakan hukum oleh Kejaksaan Negeri Bangkinang ditemukan kendala dalam penegakan hukumnya, yaitu dimana sulitnya menghadirkan saksi, baik ditingkat penyidikan maupun dipengadilan. Keterangan saksi merupakan alat bukti yang sah diatur dalam Pasal 184 ayat 1 KUHAP. Saksi adalah orang orang yang dapat memberikan keterangan guna kepentingan penyidikan, penuntutan dan peradilan tentang suatu perkara pidana yang ia dengar sendiri, ia lihat sendiri dan ia alami sendiri. Penyidik karena kewajibannya mempunyai wewenang memanggil orang untuk didengar dan diperiksa sebagai saksi. Berdasarkan hasil wawancara

9 Hasil Penelitian ICW, Hal 24-25

10 Kajian Yuridis Penerapan Unsur Merugikan Keuangan Negara dalam Penegakan Hukum Tindak Pidana Korupsi’ Diponegoro Law Journal, No. , 2017. 
dengan kejaksaan bangkinang, bahwa sulitnya menghadirkan saksi ketika di tingkat penyidikan dan peradilan. Hal ini disebabkan oleh karena saksi yang dihadirkan berasal dari desa. Oleh karena kasusnya adalah korupsi dana desa, sehingga saksi yang dihadirkan haruslah dari desa itu sendiri. Seperti pada Kasus Korupsi di Desa Gunung Malelo Kecamatan Koto Kampar Hulu, dan Desa Kampung Panjang, Desa Sungai Jalau kecamatan Kampar. Untuk di tingkat penyidikan, keterangan saksi menjadi salah satu alat bukti untuk membuat terang terjadinya peristiwa pidana. Namun pada kenyataan nya, untuk menghadirkan saksi dikejaksaan bangkinang tidaklah mudah. Karena lokasi desa yang cukup jauh dari pusat kota. Juga ketika di pengadilan, untuk kepentingan pembuktian, saksi harus dapat menyesuaiakn dengan waktu/jadwal persidangan. Sehingga hal ini agak menyulitkan kejaksaan bangkinang karena harus menghadirkan kembali saksi-saksi yang sebelumnya sudah dimintai keterangan pada waktu penyidikan.

\section{c. Terpidana tidak memiliki harta untuk membayar uang pengganti kerugian keuangan Negara}

Bahwa kewenangan kejaksaan berdasarkan Peraturan Jaksa Agung Republik Indonesia Nomor : PER- 017/ A/ JA/ 07/ 2014 tentang Perubahan Atas Peraturan Jaksa Agung Nomor: PERJA-039/A/JA/10/2010 tentang Tata Kelola Administrasi dan Teknis Penanganan Perkara Tindak Pidana Khusus, kewenangannya adalah Pra Penyelidikan, Penyelidikan, Penyidikan, Penuntutan, Upaya Hukum dan Eksekusi. Setelah perkara korupsi dana desa diputus oleh Pengadilan Tindak Pidana Korupsi Pekanbaru, maka kejaksaan sesuai kewenangannya untuk melakukan upaya hukum dan Eksekusi. Untuk kasus korupsi dana desa di kabupaten Kampar, ada dua kasus yang sudah inkracht yaitu: 1) kasus Drs. ISKANDAR, M.Si (Camat Kampar Utara dan pejabat Sementara Kepala Desa di 4 Desa) putusannya Pidana penjara 1 tahun 6 bulan Pidana denda 50.000.000, pidana tambahan Membyar uang Pengganti sebesar 274.959.700. Untuk Uang Pengganti kerugian keuangan Negara seluruhnya sudah dibayar oleh Terdakwa senilai 274.959.700; 2) kasus Suhailis Chan (ASN) Pejabat Kepala Desa Gunung Malelo Ke Koto Kampar Hulu Kabupaten Kampar) putusannya Pidana Penjara 4 tahun Pidana denda 200.000.000 Subsider penjara 6 bulan Subsider kurungan 1 bulan, pidana tambahan Uang pengganti (Subsider Denda) 261.058.551,00. Namun uang pengganti kerugian keuangan Negara tidak ada dibayar sama sekali oleh Terdakwa. Sehingga hal ini lah yang menyulitkan kejkasaan untuk melakukan Eksekusi. Untuk lebih detailnya lihat pada tabel berikut:

Tabel 1.2

Pengembalian kerugian uang negara oleh Terpidana korupsi

\begin{tabular}{|c|c|c|c|c|c|c|}
\hline No & $\begin{array}{c}\text { Nomor } \\
\text { Perkara }\end{array}$ & Pelaku & $\begin{array}{c}\text { Sumber } \\
\text { Korupsi }\end{array}$ & Tuntutan Jaksa & $\begin{array}{c}\text { Putusan } \\
\text { Akhir }\end{array}$ & $\begin{array}{c}\text { Pengembalian } \\
\text { Kerugian } \\
\text { Keuangan } \\
\text { Negara }\end{array}$ \\
\hline
\end{tabular}




\begin{tabular}{|c|c|c|c|c|c|c|}
\hline 1 & $\begin{array}{l}\text { 30/Pid.Sus- } \\
\text { TPK//2018/ } \\
\text { PN Pbr }\end{array}$ & $\begin{array}{l}\text { Drs. } \\
\text { ISKANDAR, } \\
\text { M.Si (Camat } \\
\text { Kampar Utara } \\
\text { dan pejabat } \\
\text { Sementara } \\
\text { Kepala Desa di } \\
4 \text { Desa) }\end{array}$ & $\begin{array}{l}\text { Dana } \\
\text { Desa } \\
\text { (DD) }\end{array}$ & $\begin{array}{l}\text { Pasal } 3 \text { Jo Pasal } \\
18 \text { UU Tipikor } \\
\text { Pidana Penjara } \\
2 \text { tahun } \\
\text { Pidana denda } \\
50.000 .000 \\
\text { Membayar } \\
\text { uang } \\
\text { Pengganti } \\
\text { sebesar } \\
274.959 .700 . \\
\text { jika tidak } \\
\text { dibayar diganti } \\
\text { dengan } \\
\text { pidana penjara } \\
\text { selama } 1 \text { tahun }\end{array}$ & $\begin{array}{l}\text { Pidana } \\
\text { penjara } 1 \\
\text { tahun } 6 \text { bulan } \\
\text { Pidana denda } \\
50.000 .000 \\
\text { Membyar } \\
\text { uang } \\
\text { Pengganti } \\
\text { sebesar } \\
274.959 .700 .\end{array}$ & $\begin{array}{l}274.959 .700 \\
\text { sudah dibayar } \\
\text { keseluruhannya }\end{array}$ \\
\hline 2 & $\begin{array}{l}\text { No. } \\
\text { 36/Pid.Sus- } \\
\text { TPK/2018/ } \\
\text { PN Pbr }\end{array}$ & $\begin{array}{l}\text { Suhailis Chan } \\
\text { (ASN) Pejabat } \\
\text { Kepala Desa } \\
\text { Gunung Malelo } \\
\text { Ke Koto Kampar } \\
\text { Hulu Kabupaten } \\
\text { Kampar }\end{array}$ & $\begin{array}{l}\text {-DD } \\
\text {-ADD } \\
\text {-SILPA } \\
\text { bantuan } \\
\text { Provinsi } \\
\text {-Bagi } \\
\text { Hasil } \\
\text { Pajak } \\
\text { dan } \\
\text { Retribus } \\
\text { i Daerah }\end{array}$ & $\begin{array}{l}\text { Pasal } 2 \text { Jo Pasal } \\
18 \text { UU Tipikor } \\
\text { Jo Pasal } 55 \text { ayat } \\
1 \text { ke-1 KUHP } \\
\text { Pidana Penjara } \\
5 \text { tahun dan } 6 \\
\text { bulan } \\
\text { Pidana denda } \\
200.000 .000 \\
\text { Membayar } \\
\text { uang } \\
\text { Pengganti } \\
\text { sebesar } \\
261.058 .551,72, \\
\text { jika tidak } \\
\text { dibayar diganti } \\
\text { dengan pidana } \\
\text { penjara selama } \\
2 \text { tahun } 9 \\
\text { bulan. }\end{array}$ & $\begin{array}{l}\text { Pidana } \\
\text { Penjara } 4 \\
\text { tahun } \\
\text { Pidana denda } \\
200.000 .000 \\
\text { Subsider } \\
\text { penjara } 6 \\
\text { bulan } \\
\text { Subsider } \\
\text { kurungan } 1 \\
\text { bulan } \\
\text { Uang } \\
\text { pengganti } \\
\text { (Subsider } \\
\text { Denda) } \\
261.058 .551,0 \\
0\end{array}$ & Tidak Ada \\
\hline
\end{tabular}

\section{Sumber: Data Olahan di Kejaksaan Negeri Bangkinang dan Pengadilan Negeri}

\section{Pekanbaru}

Oleh karena terpidana kasus korupsi dana desa tidak membayar uang pengganti kerugian keuangan Negara, maka mempengaruhi putusan di Pengadilan. Pidana pembayaran uang pengganti merupakan konsekuensi dari akibat tindak 
pidana korupsi yang merugikan keuangan negara atau perekonomian Negara, sehingga untuk mengembalikan kerugian tersebut diperlukan sarana yuridis yiatu berbentuk pembayaran uang pengganti. Salah satu unsur Tindak Pidana Korupsi di dalam Pasal 2 dan Pasal 3 UU 31/1999 Jo UU Nomor 20 Tahun 2001 adalah adanya kerugian keuangan Negara. Unsur tersebut memberi konsekuensi bahwa pemberantasan tindak pidana korupsi tidak hanya bertujuan untuk membuat jera para koruptor melalui penjatuhan pidana penjara yang berat, melainkan juga memulihkan keuangan Negara akibat korupsi, sebagaimana ditegaskan dalam Konsiderans dan Penjelasan Umum Undang-Undang No 31 Tahun 1999. Oleh Undang-Undang, instrument untuk memulihkan keuangan Negara tersebut dimasukkan dalam pidana tambahan berupa Pembayaran Uang Pengganti.

Pelaksanaan putusan pengadilan atau eksekusi yang telah berkekuatan hukum tetap dilaksanakan oleh Jaksa Penuntut Umum. Peran Jaksa Penuntut Umum adalah sebagai eksekutor. Pelaksanaan putusan pengadilan atau eksekusi diatur dalam Bab XIX Pasal 270 sampai Pasal 276 Kitab Undang-Undang Hukum Acara Pidana (KUHAP). Menurut ketentuan pasal 270 KUHAP bahwa " Pelaksanaan Putusan Pengadilan yang telah memperoleh kekuatan hukum tetap dilaksanakan oleh Jaksa, yang untuk itu Panitera mengirimkan salinan surat putusan kepadanya'. Eksekusi putusan Pengadilan baru dapat dilakukan oleh Jaksa, setelah jaksa menerima salinan surat putusan dari Panitera. ${ }^{11}$

Perampasan harta korupsi untuk Negara ini timbul akibat putusan hakim, dan pelaksananya merupakan kewenangan Jaksa Penuntut Umum yang melaksanakan putusan yang telah berkekuatan hukum tetap. Fungsi utama kejaksaan dalam peradilan pidana adalah sebagai Penuntut Umum dan Pelaksana Putusan Pengadilan yang telah mempunya kekuatan hukum tetap, sebagaimana disebut dalam Pasal 1 butir 1 Undang-Undang Nomor 16 Tahun 2004 tentang Kejaksaan Republik Indonesia, disebutkan bahwa Jaksa adalah " Pejabat fungsional yang diberi wewenang oleh undang-undang untuk bertindak sebagai penuntut umum dan pelaksana putusan pengadilan yang telah memperoleh kekuatan hukum tetap serta wewenang lain yang berdasarkan undang-undang.

Pasal 18 Undang- Undang Nomor 20 Tahun 2001 tentang Perubahan atas Undang-Undang Nomor 31 Tahun 1999 tentang Pemberantasan Tindak Pidana korupsi mengatur bahwa :

1) Selain pidana tambahan sebagaimana dimaksud dalam Kitab Undang-undang Hukum Pidana, sebagai pidana tambahan adalah: a) perampasan barang bergerak yang berwujud atau yang tidak berwujud atau barang tidak bergerak yang digunakan untuk atau yang diperoleh dari tindak pidana korupsi, termasuk perusahaan milik terpidana di mana tindak pidana korupsi dilakukan, begitu pula dari barang yang mengantikan barang-barang tersebut; b) pembayaran uang pengganti yang jumlahnya sebanyak-banyaknya sama dengan harta benda yang diperoleh dari tindak pidana korupsi; c) Penutupan Seluruh atau sebagian

11 Mohammad Ginanjar et al, Eksekusi Uang Pengganti Terhadap Terpidana dalam Tindak Pidana Korupsi Oleh Kejaksaan Tinggi Aceh, Jurnal Kanun Ilmu Hukum, No. 2, 2016

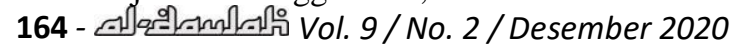


perusahaan untuk waktu paling lama 1 (satu) tahun; d) Pencabutan Seluruh atau sebagian hak-hak tertentu atau penghapusan Seluruh atau sebagian keuntungan tertentu, yang telah atau dapat diberikan oleh Pemerintah kepada terpidana.

2) Jika terpidana tidak membayar uang pengganti sebagaimana dimaksud dalam ayat (1) huruf b paling lama dalam waktu 1 (satu) bulan sesudah putusan pengadilan yang telah memperoleh kekuatan hukum tetap, maka harta bendanya dapat disita oleh jaksa dan dilelang untuk menutupi uang pengganti tersebut.

3) Dalam hal terpidana tidak mempunyai harta benda yang mencukupi untuk membayar uang pengganti sebagaimana dimaksud dalam ayat (1) huruf b, maka dipidana dengan pidana penjara yang lamanya tidak melebihi ancaman maksimum dari pidana pokoknya sesuai dengan ketentuan dalam Undangundang ini dan lamanya pidana tersebut sudah ditentukan dalam putusan pengadilan.

2. Upaya Kejaksaan Negeri Bangkinang Dalam Menangani Tindak Pidana Korupsi Dana Desa

\section{a. Melakukan Gelar Perkara}

Gelar perkara dilakukan pada tahap Penyidikan. Biasanya gelar perkara dilakukan untuk menentukan siapa tersangkanya juga untuk menghitung kerugian keuangan Negara. Dalam penelitian ini, seperti pada kasus korupsi dana desa di Bencah Kelubi Kecamatan Tapung, tersangkanya adalah Zul Anizal, namun tersangkanya melarikan diri sehingga proses penegakan hukumnya masih pada tahap Penyidikan. Selain menentukan tersangkanya, gelar perkara juga dilakukan untuk menghitung kerugian keuangan Negara. Pada proses perhitungan keuangan Negara ditemukan perbedaan persepsi antara Auditor dari Inspektorat Kabupaten Kampar dengan Auditor dari BPKP Provinsi Riau. Polres Kampar menggunakan auditor dari Inspektorat Kabupaten sedangkan Kejaksaan Bangkinang menggunakan Auditor dari BPKP Provinsi Riau. Sehingga menyebabkan perbedaan dalam perhitungan kerugian keuangan Negara. Bahwa untuk mengatasi perbedaan persepi polres Kampar dengan kejaksaan bangkinang dalam menentukan kerugian keuangan Negara, maka dilakukan gelar perkara dengan melibatkan Polda Riau, Polres Kampar, Mabes Polri, BPKP Provinsi Riau, Kejaksaan Agung, Kejaksaan Tinggi Riau dan Kejaksaan Bangkinang. Sehinga dari gelar perkara tersebut disepakati bahwa Auditor yang digunakan adalah auditor dari Inspektorat Kabupaten Kampar. ${ }^{12}$

b. Asettracing (Penelusuran Aset)

Bahwa terhadap terpidana kasus korupsi dana desa yang sudah diputus oleh Pengadilan Tipikor Pekanbaru. Wajib untuk mengembalikan kerugian keuangan Negara. Kasus Suhailis Chan (ASN) Pejabat Kepala Desa Gunung Malelo Ke Koto Kampar Hulu Kabupaten Kampar) putusannya Pidana Penjara 4 tahun Pidana denda 200.000.000 Subsider penjara 6 bulan Subsider kurungan 1 bulan, pidana tambahan Uang pengganti (Subsider Denda) 261.058.551,00. Namun uang pengganti

\footnotetext{
${ }^{12}$ Wawancara dengan Bapak Pujo, SH dan Bapak Amri Rahmanto, SH Kepala Dinas selaku Penyidik Kejaksaan Bnagkinang, tanggal 17 Juni 2019, pukul 11.00 WIB, di Kantor Kejaksaan Negeri Bangkinang
} 
kerugian keuangan Negara tidak ada dibayar sama sekali oleh Terdakwa. Sehingga hal ini lah yang menyulitkan kejkasaan untuk melakukan Eksekusi. Pihak Kejaksaann Bangkinang melakukan Penelurusan asset terhadap harta kekayaan terpidana, guna untuk mengembalikan kerugian keuangan Negara. Namun faktanya, setelah dilakukan penelusuran asset ternyata terpidana tidak ada sama sekali mengembalikan kerugian keuangan Negara. Hal inilah yang akhirnya memberatkan hukuman bagi Terpidana. ${ }^{13}$

\section{KESIMPULAN}

Dari hasil penelitian tersebut dapat disimpulkan bahwa Problematika penyidik kejaksaan negeri bangkinang dalam menangani tindak pidana korupsi dana desa diantaranya; Pertama, Adanya Perbedaan Persepsi penegak hukum dalam menghitung kerugian keuangan Negara, Kedua, Sulitnya menghadirkan saksi, Ketiga, Terpidana tidak memiliki harta untuk membayar uang pengganti atas kerugian keuangan Negara.

Upaya Kejaksaan Negeri Bangkinang dalam menangani tindak pidana korupsi dana desa diantaranya; Pertama, Penegak hukum melakukan gelar perkara dengan melibatkan Polda Riau, Polres Kampar, Mabes Polri, BPKP Provinsi Riau, Kejaksaan Agung, Kejaksaan Tinggi Riau dan Kejaksaan Bangkinang. Sehinga dari gelar perkara tersebut disepakati bahwa Auditor yang digunakan adalah auditor dari Inspektorat Kabupaten Kampar. Kedua, Kejaksaann Negeri Bangkinang melakukan Penelurusan asset terhadap harta kekayaan terpidana, guna untuk membayar uang pengganti atas kerugian keuangan Negara. Namun faktanya, setelah dilakukan penelusuran asset ternyata terpidana korupsi tidak membayar uang pengganti, sehingga lebih memilih subsider.

\section{Daftar Pustaka}

Achmad Surya, 2018. “Problematika Penyidik Dalam Penetapan Tersangka Tindak Pidana Korupsi Dana Desa Di Kabupaten Aceh Tengah". Jurnal Hukum RESAM Volume 4 Nomor 1.

Amiruddin dan Zainal Asikin, 2012, Pengantar Metode Penelitian Hukum, Jakarta: Rajawali Pers.

Budiarjo, 2014. Tindak Pidana Korupsi Alokasi Dana Desa (ADD) Desa Sei Bemban Kecamatan Kubu Kabupaten Kubu Raya Provinsi Kalimantan Barat”. Jurnal Hukum Gloria Yuris Volume 2 Nomor 4.

Evi Hartanti, 2012, Tindak Pidana Korupsi, Jakarta: Sinar Grafika Hayat, Mar'atul Makhmudah, 2016. “Pencegahan Terhadap Tindak Pidana Korupsi

\footnotetext{
${ }^{13}$ Wawancara dengan Bapak Pujo, SH dan Bapak Amri Rahmanto, SH Kepala Dinas selaku Penyidik Kejaksaan Bnagkinang, tanggal 17 Juni 2019, pukul 11.00 WIB, di Kantor Kejaksaan Negeri Bangkinang 
Pemerintahan Desa: Kajian Politik Kebijakan dan Hukum Pengelolaan Sumber Daya Alam". Jurnal Hukum Yustisia Volume 5 Nomor 2.

H.Elwi Danil, 2014, Korupsi (Konsep, Tindak Pidana dan Pemberantasannya, Jakarta: Rajawali Pers

Ida Bagus Ketut Weda. 2013. “Korupsi dalam Patologi Sosial: Sebab, Akibat dan Penanganannya Untuk Pembangunan di Indonesia". Jurnal Advokasi FH UNMAS, No. 2

Maidin Gultom, 2018, Suatu Analisis tentang Tindak Pidana Korupsi di Indonesia, Bandung: Refika Aditama.

Marten Bunga dkk, 2018. “Konsepsi Penyelamatan Dana Desa dari Perbuatan Korupsi”. Jurnal HOLREV (Halu Oleo Law Review), Volume 2 Nomor 2.

Mohammad Ginanjar et al, 2016. "Eksekusi Uang Pengganti Terhadap Terpidana dalam Tindak Pidana Korupsi Oleh Kejaksaan Tinggi Aceh, Jurnal Kanun Ilmu Hukum, Nomor 2

Kajian Yuridis Penerapan Unsur Merugikan Keuangan Negara dalam Penegakan Hukum Tindak Pidana Korupsi' Diponegoro Law Journal, Nomor. 1 (2017) . 